\title{
宇宙の微小重力環境を用いた 溶融半導体の熱伝導率测定
}

中村新*，日比谷孟俊*

株式会社宇宙環境利用研究所

T102 東京都干代田区九段北 $1-4-5$

\begin{abstract}
本稿では、まず融点付近での溶融半導体 $(\mathrm{Si}, \mathrm{Ge}, \mathrm{GaSb}, \mathrm{InSb})$ の熱伝導率について概説 した。主に自然対流の影響を受けて、測定された溶融半導体の熱伝導率には、測定によ って大きなデータのばらつきが見られる。この対流を抑制する方法として微小重力環境 と磁場の利用が考えられる。現在までに実施または計画された微小重力下での熱伝導率 測定について紹介し、加えて磁場中での水銀の熱伝導率測定結果についてもふれた。
\end{abstract}

1.はじめに

高品質の半導体結晶を得るために，結晶成長時の 系全体の “熱と物質の流れ”を理解し制御すること が重要である。将来は，結晶成長過程での“熱と物， 質の移動”をスーパーコンピュータを駆使して計算 し，逐次，成長結晶へのドーパントや不純物の取込 まれかたを予測しながら結晶成長を行うようになっ てゆくと考光られる、コンピュータによる䐍大な計 算を行うためには，計算の境界条件をより現実のも のとすると同時に，材料の正確な熱物性值が必要に なる。現在，結晶引上状時の坩堝内の流れに焦点が あてられていることからわかるように，とくに溶融 状態での熱物性值を知る必要がある。

ここで注目している物質は，シリコンやグルマニ ウムなどの単体半導体と GaAs や InSb などの化合 物半導体である。これらの物質の溶融状態における 熱物性定数のうち, 熱伝導率 (もしく山熱拡散率) と粘性係数が自然対流を検討するために，また，表 面張力がマランゴニ対流を検討するために必要にな る．地上での結晶成長を問題にするならば，自然対 流が支配的であろうから，まず必要な物性值は粘性 係数と熱伝導率ということになる。

* 日本電気株式会社より出向中
Table 1

Thermal conductivity of semiconductors at melting points

\begin{tabular}{|c|c|c|c|c|c|}
\hline & $\begin{array}{l}\text { Liquid } \\
(\mathrm{W} / \mathrm{mK})\end{array}$ & $\begin{array}{l}\text { Sol id } \\
(\mathrm{H} / \mathrm{mK})\end{array}$ & Year & Method & REF. \\
\hline $\mathrm{Si}$ & $\begin{array}{l}209 \\
66.9 \\
56\end{array}$ & $\begin{array}{l}66.9 \\
31.4 \\
27.3\end{array}$ & $\begin{array}{l}1965 \\
1966 \\
1989\end{array}$ & $\begin{array}{l}A \\
A \\
C\end{array}$ & $\begin{array}{r}2 \\
3 \\
15\end{array}$ \\
\hline \multirow[t]{3}{*}{$\mathrm{Ge}$} & 48.5 & $17.1,35.9$ & 1963 & & 4 \\
\hline & $\begin{array}{l}71.1 \\
25 .\end{array}$ & $\begin{array}{l}24.3 \\
16.0\end{array}$ & $\begin{array}{l}1964 \\
1971\end{array}$ & $\begin{array}{l}\text { A } \\
B\end{array}$ & $\begin{array}{l}5 \\
6 \\
7\end{array}$ \\
\hline & $\begin{array}{l}50.1 \\
38.1\end{array}$ & $\begin{array}{l}18.9 \\
14.9\end{array}$ & $\begin{array}{l}1973 \\
1982\end{array}$ & C & 8 \\
\hline $\mathrm{GaSb}$ & 17.4 & 8.2 & 1966 & D & 9 \\
\hline \multirow{3}{*}{ InSb } & $\begin{array}{r}6.5 \\
13.0\end{array}$ & $\begin{array}{l}4.0 \\
4.6\end{array}$ & $\begin{array}{l}1970 \\
1965\end{array}$ & $\begin{array}{l}E \\
D\end{array}$ & $\begin{array}{l}10 \\
11\end{array}$ \\
\hline & 17.1 & 4.8 & $\begin{array}{l}1965 \\
1970\end{array}$ & $\mathrm{E}$ & 10 \\
\hline & 18.0 & & 1988 & $\stackrel{\mathrm{L}}{\mathrm{F}}$ & 13 \\
\hline
\end{tabular}

Method; A: Crystal pulling experiment

B: Coaxial cylinder method Flat layer method C: Laser flash method D: Steady-State method E: Cylindrical instrument F: Hot wire method 
溶融半導体の物性值については Glazov らによる “ Liquid Semiconductors ”がよく知られてい る[1]。粘性係数は表としてまとめられているが, 熱伝導率に関するデータは載っていない，後で述べ るように, 現状では溶融半導体の熱伝導率の信頼す べき值は皆無と言っても過言ではない。この原因の 一つとして, 自然対流が測定值に大きく影響するこ とが考えられる。実際の測定において如何にこの自 然対流を押さえるかが課題である.

ここでは, 現在知られている溶融半導体の熱伝導 率値を紹介し，測定を行う上での課題についてまと めた．それらの内とくに，対流を押さえる2つの方 法,すなわち，微小重力環境の利用と，外部磁場の 利用について述べた，最近の微小重力環境での，幾 つかの熱伝導率測定について紹介する，あわせて， 外部磁場が熱伝導率測定に及ぼす磁場制動の効果に ついて述べる。

\section{2. 溶融半導体に扔ける熱伝導率測定值}

単体および化合物半導体の溶融状態での熱伝導率 の測定に関しては, 現在まで限られた報告しかない。 これらをTable 1 にまとめて抒く，測定は 1960年 代に多く行われており，多くはソ連の研究者よって いるのが特徴的である. 固体状態での測定結果も参 考のために載せておく，融点付近での固体状態の熱 伝導率測定は，ここに挙げる他にかなりの数が報告 されており [14]，それらと比較することにより固体 状態での熱伝導率を吟味することはできる。しかし， 溶融状態での熱伝導率をこれらから推定することは 困難に思われる。

表に示すシリコンの熱伝導率測定のうち文献 [2] と [3]では, 結晶引き上げ時の固液界面の温度勾配 を結晶を引上げながら測定することにより，熱伝導 率測定が決定された。文献 [5] に拈けるグルマニ ウムの測定結果もその測定法にによるものである. この方法は実験条件によっては〜200(W/mK) という 大さな值を示すこともあり，データを使用する際の 注意が必要である。最近, レーザーフラッシュ法 を用いて 溶唡シリコンの熱伝導率測定が行われ, $56(\mathrm{~W} / \mathrm{mK})$ という報告がなされた[15]。計算機シミ ユレーションにおいては, 30〜60（W/mK）の值が使 われている。熱伝導率值を変えたシミュレーション をすることにより，その効果について検討した報告 例もある[16]。

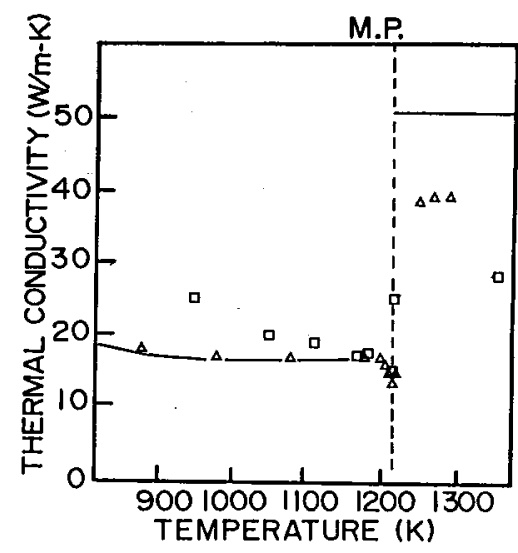

Fig. 1 Thermal conductivity of Germanium[8] $\square:$ Ref. [6] -: Ref. [7] $\triangle$ : Ref. [8]

ゲルマニゥムは，シリコンに較べるとデータ数も 多く，また異なった方法で測定されている．測定が 多い理由は, シリコンに較べると低融点であり化合 物半導体のように V 属元素の高い蒸気圧を持たない ことから，測定が容易であるためと考えられる。こ れらのデータから溶融半導体の熱伝導率の融点近傍 での一般的な傾向を示すことができる.Fig. 1 は， 融点附近でのゲルマニウムの熱伝導率测定值をなと めたものである [8]。半導体は融解することにより 半導体一金属転移をおこす。このため溶瀜状態では キャリア濃度が上昇し，熱伝導率が上昇する。その 傾向は融点での熱伝導率の不連続な上昇により明確 に示されている。しかし溶融状態での熱伝導率の絶 対值ということになると,やはり断定はできないこ とがこの困からもあきらかである。

化合物半導体の熱伝導率測定例は, わずかにアン チモン系の比較的低融点の化合物のみに限られてい る. GaAs と InP に対しては, 固体状態と溶融状態 の熱伝導率の比を仮定することにより，溶辟状態の 熱伝導率を推定した報告はあるが [17], 実測例はな い。

ひ素化合物やりん化合物の報告がないのは，あき らかに測定上の困難性に拠っている，液体金属の熱 伝導率が比較的高融点のものまで測定されているこ とを考えあわせると, 溶䖯半導体の熱伝導率測定を 困難にしている理由の一つは，その物質の化学的な 扱いにくさ（腐食性と高い蒸気圧）によるものであ る。 
Table 3

Thermal conductivity measurements in space

\begin{tabular}{lll}
\hline Flight & Material & Method \\
\hline 1. Space Lab. & Liquid metal & Stationary \\
2. Space Lab. & Silicon oil & Hot wire \\
3. MASER & $\begin{array}{l}\text { Non electrically } \\
\text { conductive Hot Wire }\end{array}$ & \\
4. GAS & Silicon oil & Hot Plate \\
5. TEXUS & Molten InSb & Hot wire \\
\hline
\end{tabular}

1: $\operatorname{Ref}[18] 2: \operatorname{Ref}[19] 3: \operatorname{Ref}[20]$

4: $\operatorname{Ref}[21]$ 5: $\operatorname{Ref}[22]$

GAS を利用して,シリコンオイルの熱伝導率測定 を行うことが現在計画されている[20]。この測定で は，宇宙実験用に改良された平板法を用いる予定で ある。

Table 3 によっても分るように, 非定常細線法 ( Transient Hot Wire Method) の原理にもとずく ものが多い。この方法は, 短時間に測定が終了でき るという利点があり，宇宙実験に適していると言え る. Fig. 2 に測定時間に対する細線の温度上昇を トルエンを例に取って示す [19]，地上に於いては $\mathrm{A}$ やBの場合のように，配置に依存して異なる時間か ら対流が発生しているのが, 宇宙においては C の場 合のように, 対流が抑制され精度のよい測定が可能 になる。このように微小重力環境利用の顕著な効果 が期待できる点でも，非定常細線法は宇宙実験に適 している。

表中 2.で示される，Space Lab. で計画された実 験は，一般的な細線法のように金属細線の抵抗值を 測定するのではなく，金属細線を発熱させたときの 細線の周りの温度場をホログラフにより直接観察す る方法を取っている[19]，小型ロケットを用いた熱 伝導率測定としては，スウェーデンのメーザーロケ ット（MASER）を利用した非定常細線法による熱 伝導率測定が，非電気伝導性液体に対して行われて いる[21].

筆者らは，非定常細線法を応用したセラミックプ ローブをもちいて西ドイッのテキサス ロケット (TEXUS) を利用して, 溶融 InSb の熱伝導率測定を 計画している [22]。溶融半導体は液体金属的で電気 伝導性があるので，細線法を用いる場合，発熱体に 何らかの絶縁を施さなければならない。また打ち上
げ時の振動や加速度に耐えなければならない。そこ で, 細線を厚いアルミナ基板上に形成し，さらに薄 い絶縁層を形成したセラミックプローブを作製した [23]. Fig. 3 にそのセラミックプローブを示す. このプローブの作製には，多層セラミック基板の技 術を応用している．焼結前のグリーンシート上に白 金細線および電極部を印刷により形成し，さらに絶 縁膜を印刷したものを高温において焼結する。焼結 後プローブは円筒形に削り出される。

Fig. 4 にはこのプローブを用いて，地上におけ る予備実験として測定した溶融 InSb の熱伝導率測

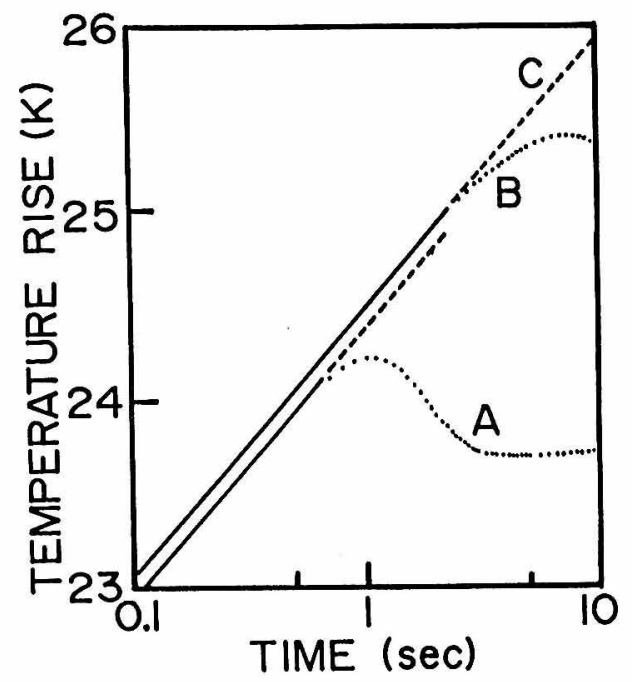

Fig. 2 Temperature rise of wire[19]

A: Horizontal position

B: Vertical position

C: Extrapolated to zero gravity

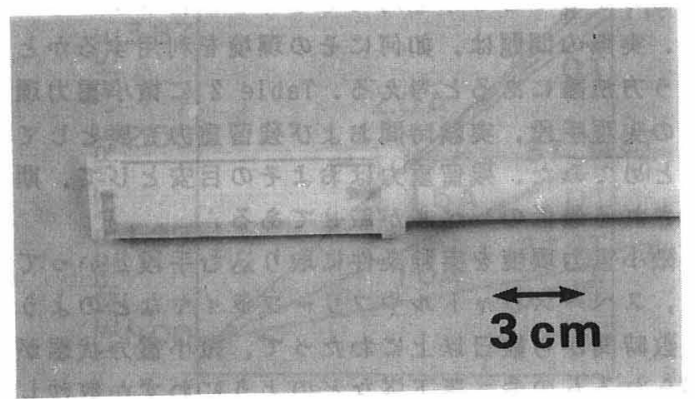

Fig. 3 Ceramic Probe 


\section{3. 熱伝導率測定に扮ける対流の抑制方法}

測定されたデータの信頼性を評価する際にまず はじめに検討しなければならないのは測定時の試料 の対流の有無である。これは高温融体で比較的低粘 性の物質の熱伝導率測定では，かならず問題になっ てくる．例えば，シリコンの熱伝導率測定の場合の ように結晶成長中の固液界面での温度勾配を測定す る方法では，坩堝内の対流の抑制がどの程度なされ ていたかは明確でない[2]，一般的な結晶成長炉で は，対流はかなり発生しているからである。

熱伝導率測定において対流を抑制するためには， 測定試料のレイリ一数を対流が発生しないように小 さくすればよい，

レイリー数を小さくするーつの方法は，重力方向 に液体試料厚さを薄くすることである。測定中に臨 界レイリー数を越えなければ対流が発生せず測定が 行える。レーザーフラッシュ法や平板法ではこれを 利用している、微小重力環境では重力を小さくする ことにより，レイリー数を小さくすることができる。 測定試料の大きさの制限が弱くなることが, 測定環 境を変えてしまう利点であると考える。

測定対象が電磁流体に限られるが, 外部磁場によ っても対流を狮制することができる。磁場中では電 磁流体の運動が，磁場によるローレンッカによって 抑制されるからである。この方法は，測定対象の実 効粘性係数を大きくすることにより,レイリ一数を 小さくしている。

\section{4. 微小無重力環境での熱伝導率測定}

対流を完全に抑制するには，微小重力環境を利用 するのがもっとも原理的であることは言うまでもな い。実際の問題は，如何にその環境を利用するかと いう方法論にあると考える. Table 2 に微小重力環 境の実現手段，実験時間抒よび残留重力を表として まとめてみた。残留重力は书よその目安として, 期 待される最低のレベルが載せてある。

微小重力環境を実験条件に取り込む手段といって も，スペースシャトルやフリーフラ゙イヤなどのよう に数時間から数日以上にわたって, 微小重力状態が 得られるものや，落下塔などのようにわずか数秒し か得られないものもある.小型口ケットなら数分か ら十数分である.フリーフライヤとは，軌道上を飛 行する無人の実験用衛星で, スペースシャトルによ
り地球をまわる軌道上にのせられ，数カ月の実験後 再びスペースシャトルによって回収されるものであ る.また, Get Away Special (GAS) とは,スペー スシャトルのあきスペースに完全自動の装置を積み 込み, 飛行士によるスイッチのオン,オフ(と非常 停止スイッチ)だけで実験を無重力環境で行ってく るものである．長時間を要する定常法の実験であれ ば、シャトルなどが適当であろう。小型口ろットは, 比較的容易に利用できるランチャーではあるが微小 重力の時間が制約されるので, 測定は非定常法に限 られる。

微小重力と呼ばれるように残留重力はゼロではな い。そこで,どの程度のGレベルが許容される実験 なのかも重要になってくる.予想される残留重力は

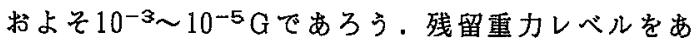
まり問わない場合や予備実験であるなら航空機実験 も考えられる。高品位の微小重力環境の実現は，フ リーフライヤによって可能であると考える. 飛行士 が乗っているシャトルやステーションでは人間や機 械による重力の変動 (G-jitter) が大きな問題に なるからである。実験目的にかなった手段（時間と 残留重力) を選択することが, 費用のかかる微小重 力実験では重要である。

現在までに5つの熱伝導率測定が計画もしくは実 行された。それらをTable 3 にまとめて书く.

もっとも初期のものは，スペースラブ(Space Lab) 計画を目標に計画された液体金属の熱伝導率測定で ある[18]．この計画に関するフライト結果の報告が 見当らないので, 実際には行われなかったようであ る。

Table 2

Microgravity Capabilities

\begin{tabular}{lcc}
\hline & Duration & $\begin{array}{c}\text { Gravity } \\
\left(X 9.8 \mathrm{~m} / \mathrm{s}^{2}\right)\end{array}$ \\
\hline Drop tower & $4-10 \mathrm{sec}$. & $10^{-5}$ \\
Aircraft & $20 \mathrm{sec}$. & $10^{-2} \sim 10^{-3}$ \\
Sounding rocket & $5-15 \mathrm{~min}$. & $10^{-4}$ \\
Space shuttle & $>1 \mathrm{~h}$ & $10^{-4}$ \\
Get Away Special & $>1 \mathrm{~h}$ & $10^{-4}$ \\
Free flyer & $>10 \mathrm{~h}$ & $10^{-6}$ \\
Space station & $>10 \mathrm{~h}$ & $10^{-5}$ \\
\hline
\end{tabular}




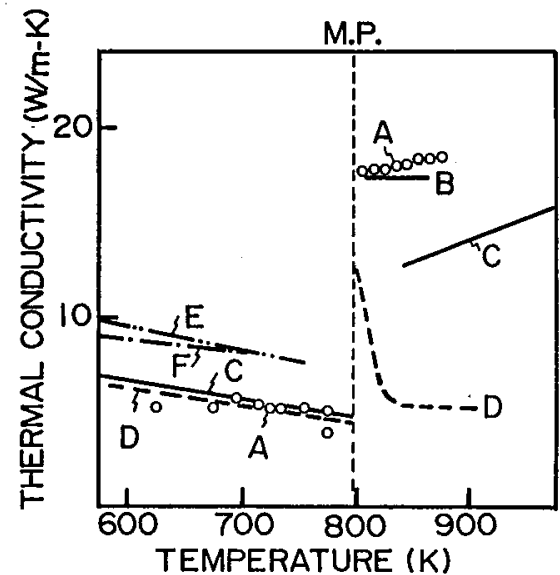

Fig. 4 Thermal Conductivity of Molten InSb A: Authors [13] B: Ref [12] C: Ref [10] D: Ref[11] E: Ref [24] F: Ref [25]

定結果を示す [13]．Fig. 1 に示す，ゲルマニウム 測定結果の同様に溶融することにより熱伝導率は融 点で不連続に上昇する.この測定結果は, 他の報告 值よりも高く，ウィーデマン・フランッの法則から 予想される熱伝導率值 $19(\mathrm{~W} / \mathrm{mK})$ [融点］に近い. ウィーデマン・フランッの法則は液体金属でよく成 立つ法則である.Glazovらは溶融状態においてInSb ‘ が液体金属的であると報告している[26]．宇宙実験 により正確な熱伝導率が測定されれば，液体金属的 であるかどうかを確かめられるであろう。

宇宙実験に括ける実験技術上の幾つかの点につい て，ここで簡単にまとめてみたい.

一つには実験装置の操作の問題である.スペース シャトルとステーションに书いては, 飛行士による 実験のコントロールが行われる. 微妙な操作技術を 要する実験では地上からの遠隔操作によることもあ る.しかし GAS, フリーフライヤ, ロケットなど の実験では完全自動な実験装置を準備する必要があ る. 例えば, 非定常細線法などでは, 一般にはブ リッジ回路などをもちいて微小な細線の温度上昇を 測定する．ところが宇宙実験では，手による微妙な 調整はすべてプログラム化され，自動的に行われ なければならない。

地上においては, 自然対流が支配的であるが，宇 宙においては，マランゴニ対流の影響が大きな問題 になる。液体試料に温度差をつける場合には, 自由 表面をなくすことによってはじめて完全な無対流状
態が得られる. 熱伝導率測定においては温度差をつ けることは避けられない条件であるので, 自由表面 をなくすように，実験装置を設計することが重用な 点になる。

また，実験がシャトルやフリーフライヤのような 狭い空間内で行われるため，一般には想像できない ような実験条件，実験環境に対する検討の必要性が でてくる.たとえば, シャトルが太陽に対してどの 方向を向いているかによって装置の温度環境が変化 することを考虑しなければならないような場合もあ る [21]. 安全上の問題や打ち上げ時の加速度にた いする装置の保証についても，実験前にかなりよく 検討されなければならない点である。

\section{5. 磁場中の熱伝導率測定}

対流を抑制するもう一つの方法は外部磁場の印加 によるものである [28]. 結晶成長において温度振動 の原因となる非定常流を押さえ，定常流とする目的 で成長中の融液に磁場を印加することが一般的に行 われている。しかし，熱伝導率測定においては流れ そのものを止める必要があり, 磁場の大きさも従来 以上のものが要求される。このため測定方法, 装置 に制限が付く可能性はある.しかし, 磁場制動の効 果は電気伝導性液体の熱伝導率測定に極めて有効で あると考えられる。

現在まではシミュレーションなどでその効果が予 測されていたが [28]，筆者らは実際に熱伝導率測定 セルに磁場を印加した状態で測定を行った [29]。こ の測定に拈いてもセラミックプローブを使用した。

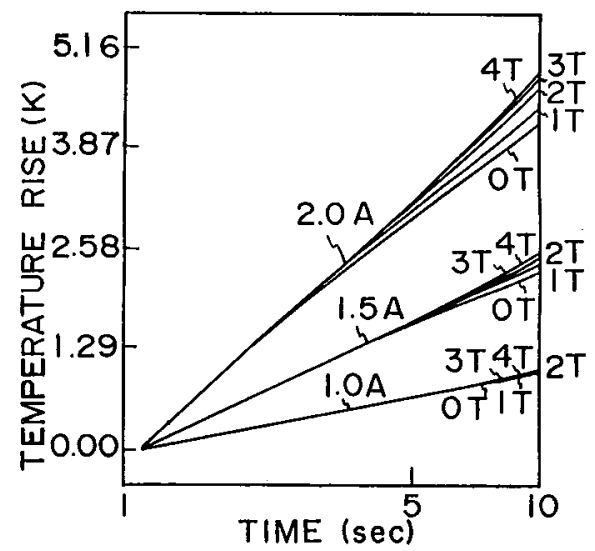

Fig. 5 Temperature $r$ ise of wire[29] 
セラミックプローブは細線部が丈夫なアルミナ基板 に固定されているので，ローレンッカにより細線が 湾曲したり，破断したりはしない，Fig，5には磁場 を 4 テスラまで加えた時の細線の温度上昇を示す。 $1.0 \mathrm{~A}, 1.5 \mathrm{~A}$ 㐨よび $2.0 \mathrm{~A}$ は細線に加えた電流值 である、磁場を印加するとともに対流の発生が抑制 されていくことが，とくに2.0A の場合に顕著に 示されて抒り，外部磁場の効果が認められる。

前章に述べたように，スペースシャトルなどでは， 残留重力の変化が低粘性の流体に極めて大きな影響 を及ぼす。例えば，G-jitterにより発生した対流 が慣性によって流れ続けることがある。そこで宇宙 に磁場を持込もうという提案もなされている。低重 力下では対流抑制のために必要な磁場は地上より弱 くて済み，実現が技術的に可能な大きさの磁場によ って,さらに精度の良い熱伝導率測定が可能になる かもしれない。

$$
\text { 6.まとめ }
$$

溶融半導体の熱伝導率測定と, 無重力環境に抢け る熱伝導率測定について紹介した。溶融半導体のよ うな低粘性流体は，対流の影響を受けやすいことか ら, 宇宙環境の利用が対流の問題の原理的解決策と なる。このため様々な方法の測定がなされている. また，電気伝導性液体の熱伝導率測定にたいしては 磁場の利用の可能性も十分ある。そして将来には， 微小重力環境と磁場とを併用することも行われるだ ろう。

3章に述べたように, 宇宙実験に於いては実験装 置の設計，作製が極めて重要な課題になる。沉用性 の高い実験装置がもちろん望ましい。しかし実際に は実験者が意図する個々の実験は，必ずしも沉用装 置で実現できるとは限らない，やや装置至上主義的 な感じのする出来合い装置での宇宙実験が多いが, "Hand made "の実験装置,つまり実験者自身が使 いなれている実験装置で実験することがもっとも理 想的でありかつ必要ではないだろうか。というのは， 宇宙実験は必ず地上での比較実験を必要とし, 宇宙 実験用の特別な条件下でしか㬰験できないような装 置では何にもならないからである，加えて，宇宙実 験は地上のための実験でなければならない。いまあ る実験装置をそのまま宇宙に持って行って実験する という感賞が, もっとも実用的であり, かっ, 地上 にフィードバックできる有用な情報を得る手段と考
える。

宇宙実験はもはや遠い将来の夢のような実験では ない，溶融半導体の熱伝導率測定に限らず，様々な 問題を新しい角度から考えてみる一つの手段である。 地上の実験では想像だにしなかった問題点を，検討 し, 解決してゆく過程に书いて新しい知見や発見が あるように思う。

\section{参考文献}

[1] V. M. Glazov, S. N. Chizhevskaya, N. N. Glagoleva, "Liquid Semi conductors" (Plenum press, New York, 1969).

[2] M. G. Mil'vidskii, V. V. Eremeev, Soviet Phys. Solid State, 6(1965) 1549/1552.

[3] Yu. M. Shashkov, V. P. Grishin, Soviet Phys. Solid State, $8(1966) 447 / 448$.

[4] D. R. Hamilton, R. G. Seidensticker, J. App 1. Phys. $34(1963) 1450$.

[5] J. C. Brice, P. A. C. Whiffin, Solidstate Electronics, 7(1964) 183/187.

[6] V. M. Glazov, A. A. Aaivazov, V. G. Pavlov, Soviet Phys. Semicond., 5(1971) $182 / 185$.

[7] L. P. Filippov, Int. J. Heat Mass Transfer, 16 (1973) 865 .

[8] R. K. Crouch, A. L. Fripp, W. J. Debnam, R. E. Tayor, H. Groot, "Materials Processing in the Reduced Gravity Environment of Space", (Elsevier Science Publishing Company, New York, 1982), 657/663.

[9] Kh. I. Amirkhanov, Ya. B. magomedov, Soviet Phys. Solid State, $8(1966) 241 / 243$.

[10] V. I. Fedorov, V. I. Machuev, High Temp., $8(1970) 419 / 421$.

[11] Kh. I. Amirkhanov, Ya. B. magomedov, Soviet Phys. Solid State, $7(1965) 506 / 508$.

[12] V. I. Fedorov, Proc. of the Moscow Power Engineering Institute, 63(1965) 193.

[13] S. Nakamura, T. Hibiya, F. Yamamoto, Int. J. Thermophys. $9(1988) 933 / 940$.

[14] P. D. Maycock, Solid State Electronics, $10(1967) 161 / 168$.

[15] K. Yamamoto, T. Abe, S. Takasu, Proc 10th Jpn. Symp. on Thermophysical Properties, (1989) $119 / 122$.

[16] L. N. Hjellming, J. S. Walker, J. Crystal Growth, $87(1988) 18 / 32$.

[17] A. S. Jordan, J. Crystal Growth, 71(1985) $551 / 558$. [18] H. Coenen, Tech. Mitt. Krupp Forsch. Ber.,
$37(1979) 83 / 90$. 
[19] K. Wanders, Proc. 4th European Symp. on Material Sciences under Microgravity Condictions, (ESA SP-191,1983) 403/408.

[20] R. Jonsson, XXXVII IAF Congress, (1986) 289.

[21] J. C. Perron, Proc. 6th European Symp. on Material Sciences under Microgravity Conditions, (ESA SP-256, 1987), 509/515.

[22] S. Nakamura, T. Hibiya, T. Yokota, F. Yamamoto, ICCG-9 Abstracts (1989) 15.

[23] S. Nakamura, T. Hibiya, F. Yamamoto, Rev. Sci. Instrum., 59(1988) 2600/2603.

[24] R. Bowers, R. W. Ure, J. E. Bauerle, A. J. Jo/ 334 .

[25] G. Busch, E. Steigmeier, Helv. Phys. Acta, $33(1961) 1$.

[26] V. M. Glazov, A. A. Aivazov, V. B. Kol'tsov, Soviet Phys. Semicond. 14 (1980) 909/913.

[27] S. Chandrasekhar "Hydrodynamic and Hydromagnetic Stability", (Clarendon Press, Oxford, 1961).

[28] H. 0zoe, E. Maruo, JMSE Int. J. 30 (1987) $774 / 784$.

[29] S. Nakamura, T. Hibiya, F. Yamamoto, T. Yokota, Proc, 10th Jpn. Symp. Thermophysical Properties, (1989), 91/94.
Thermal Conductivity Measurement of Molten Sem iconductors under Microgravity Environment in Space

S. Nakamura, T. Hibiya Space Technology Corporation Kudankita 1-4-5, Choyoda-ku Tokyo, 102

Thermal conductivities of molten semiconductors ( $\mathrm{Si}, \mathrm{Ge}, \mathrm{GaSb}$ and $\mathrm{InSb}$ ) near their melting points are reviewed. Measured thermal conductivities show different values depending on measurement methods. This is mainly due to natural convection during measurements. In order to reduce this convection, two approaches can be considered; utilization of microgravity environment and magnetic field. Thermal conductivity measurements in microgravity, some of which were already carried out and the others in future, are also summarized in this review. Recent results of thermal conductivity measurement for mercury in a magnetic field are shown.

(Received on Sep. 6, 1989) 